\title{
Hubungan antara Status Kontrol Glikemik, Vitamin D dan Gizi pada Anak Diabetes Melitus Tipe 1
}

\section{Relationship between Glycemic, Vitamin D and Nutrition Status Control in Children with Type 1 Diabetes Mellitus}

\author{
Ratna Indriyani, Harjoedi Adji T \\ Laboratorium IImu Kesehatan Anak Rumah Sakit Umum Daerah Dr. Saiful Anwar Malang
}

\begin{abstract}
ABSTRAK
Di beberapa negara barat kasus DM tipe-1 adalah 5-10\% dari kasus diabetes, dan lebih dari 90\% penderita diabetes pada anak dan remaja adalah DM tipe-1. Vitamin D berperan penting dalam membangun dan memelihara mineralisasi tulang. Defisiensi vitamin D dapat menyebabkan penekanan bone turnover sehingga menyebabkan gangguan kecepatan tinggi badan. Kontrol glikemik yang buruk berupa $\mathrm{HbA1c}$ yang tinggi dapat menyebabkan berat dan tinggi badan tidak naik secara adekuat. Penelitian ini bertujuan untuk membuktikan hubungan antara status kontrol glikemik(HbA1c), status vitamin D (25(OH)D), dan status gizi pada anak DM tipe-1. Desain penelitian berupa studi cross-sectional dilakukan pada 28 subjek penelitian yaitu anak DM tipe 1 usia 1-18 tahun yang menjalani rawat jalan di Poli Endokrinologi Rumah Sakit Umum dr. Saiful Anwar Malang. Kriteria eksklusi yaitu menderita penyakit autoimun lain, infeksi berat, gangguan hati, gangguan fungsi ginjal dan anemia. Variabel yang diukur status gizi, kadar HbA1c dan 25(OH)D. Untuk mengetahui perbedaan rerata kadar 25(OH)D dan HbA1c berdasarkan status gizi digunakan uji beda Kruskal wallis, dan uji korelasi Spearman. Dari 28 subjek didapatkan 68\% anak dengan status gizi baik, 64\% anak dengan kontrol metabolik buruk dan $61 \%$ anak dengan defisiensi/insufisensi $25(\mathrm{OH}) \mathrm{D}$. Tidak terdapat hubungan yang bermakna antara status gizi, kontrol glikemik, dan vitamin $\mathrm{D}$.
\end{abstract}

Kata Kunci: Diabetes melitus tipe 1, HbA1c, status gizi, status kontrol glikemik, status vitamin D

\section{ABSTRACT}

In some western countries, type-1 diabetes cases are 5-10\% of diabetes cases, and more than $90 \%$ of diabetics in children and adolescents are type 1 DM. Vitamin D plays an important role in building and maintaining bone mineralization. Vitamin D deficiency can cause bone turnover suppression, thus causing height growth disorders. Poor glycemic control in the form of high HbA1c can cause weight and height not to increase adequately. This study aimed to prove the relationship among control glycemic status ( $\mathrm{HbA1C})$, vitamin D status $(25(\mathrm{OH}) \mathrm{D})$, and nutritional status in children with type-1 DM. The study design was a cross-sectional study conducted on 28 research subjects, namely children with type 1 DM aged 1-18 years who underwent outpatient care at the Endocrinology Polyclinic of Dr. Saiful Anwar General Hospital Malang. The exclusion criteria were suffering from other autoimmune diseases, severe infections, liver disorders, impaired kidney function, and anemia. Variables measured were nutritional status, $\mathrm{HbA1C}$, and 25(OH)D levels. To find out the differences in the mean levels of 25(OH)D and HbA1c based on nutritional status, Kruskal wallis test and Spearman correlation test were used. Of the 28 subjects $68 \%$ of children were found with good nutritional status, $64 \%$ of children with bad metabolic control, and $61 \%$ of children with $25(\mathrm{OH}) \mathrm{D}$ deficiency/insufficiency. There is no significant relationship between nutritional status, glycemic control, and vitamin $D$.

Keywords: Control glycemic status, HbA1c, nutrition status, type 1 diabetes mellitus, vitamin D status

Korespondensi: Ratna Indriyani. Laboratorium IImu Kesehatan Anak Rumah Sakit Umum Daerah Saiful Anwar Malang, Jl. Jaksa Agung Suprapto No. 2, Malang Tel.(0341)362101Email: ratnaindriyani14@gmail.com 


\section{PENDAHULUAN}

Diabetes melitus (DM) tipe-1 merupakan salah satu penyakit kronis yang sampai saat ini belum dapat disembuhkan $(1,2)$. Penyakit ini merupakan penyakit kronik dengan gangguan metabolisme karbohidrat, lemak, dan protein dengan penyebab defisiensi insulin akibat destruksi autoimun sel beta pankreas (3).

Insiden DM tipe-1 sangat bervariasi baik antar negara maupun dalam satu negara. Di beberapa negara barat kasus DM tipe-1 adalah 5-10\% dari seluruh kasus diabetes, dan lebih dari $90 \%$ penderita diabetes pada anak dan remaja adalah DM tipe-1. Insiden tertinggi terdapat di Finlandia yaitu 43/100.000 dan insiden yang rendah di Jepang yaitu 1,5-2/100.000 untuk usia kurang 15 tahun $(2,3)$. Insiden DM tipe-1 lebih tinggi pada ras Kaukasia dibandingkan ras-ras lainnya. Diperkirakan di seluruh dunia 80.000 anak-anak berusia kurang dari 15 tahun akan berkembang menjadi DM tipe-1. Data registri nasional DM tipe-1 pada anak dari Pengurus Pusat Ikatan Dokter Indonesia (PPIDAI) hingga tahun 2014 menunjukkan 1021 kasus (4). Di Rumah Sakit Dr. Saiful Anwar (RSSA) Malang antara tahun 2011-2016 terdapat 60 pasien diabetes melitus tipe 1 dengan usia 1-18 tahun (5).

Etiologi DM tipe 1 multifaktorial meliputi faktor genetik, lingkungan, dan sistem imun. Mekanisme perusakan sel $\beta$ sampai saat ini masih dalam perdebatan, namun jelas bahwa keterlibatan sistem imun, yaitu makrofag dan sel T, dan sitokin, sangat besar. Faktor inflamasi, spesies oksigen reaktif, dan reaksi autoimun muncul sebagai efektor patogenik DM tipe 1 (6-9).

Defisiensi vitamin D dapat meningkatkan risiko berkembangnya penyakit autoimun termasuk DM tipe 1 akibat hilangnya modulasi vitamin $D$ terhadap sistem imun dan reaksi inflamasi pada diabetes $(6,10,11)$. Penelitian in vitro menunjukkan bahwa vitamin $D$ bersifat imunosupresif atau sebagai imunomodulator sedangkan penelitian model eksperimental tentang penyakit autoimun, termasuk DM tipe 1 menunjukkan bahwa vitamin $\mathrm{D}$ bersifat protektif. Penelitian observasional lainnya juga menunjukkan korelasi positif antara kadar vitamin $D$ dengan sensitivitas insulin dan fungsi sel beta pankreas (11). Pada tulang rangka, vitamin D mempunyai peran yang sangat penting dalam membangun dan memelihara mineralisasi tulang. Pertumbuhan tulang membutuhkan kalsium dan $1,25(\mathrm{OH})_{2} \mathrm{D}$ untuk membangun pembentukan osteoblastik tulang optimal (12).

Keterlibatan faktor genetik, lingkungan dan proses autoimun merupakan mekanisme yang berperan pada terjadinya DM tipe 1. Interaksi antara faktor genetik dan lingkungan memicu respon imun berupa proses autoimun. Vitamin D merupakan hormon yang disintesis di dalam tubuh dan beraktifitas pada berbagai macam organ melalui reseptor vitamin D (VDR). Sebagian besar penderita DM tipe 1 mengalami defisiensi vitamin D, baik karena kurangnya paparan sinar UV atau intake vitamin D yang tidak adekuat. Kadar 25(OH)D yang rendah dapat mempengaruhi sistem imun dengan berbagai cara, sehingga terjadi respon imun patogen dan dapat memicu destruksi sel $\beta$ pankreas. Pada proses destruksi sel $\beta$ pankreas terjadi infiltrasi pulau-pulau Langerhans oleh sel-sel inflamasi melalui perusakan selektif dan spesifik terhadap sel $\beta$ pankreas sehingga menyebabkan terjadinya insulitis dan penurunan kadar insulin (7-9). Jika kadar insulin turun maka akan terjadi hiperglikemia yang jika berlangsung kronis berakibat pada kenaikan HbA1c sebagai indikator kontrol glikemik. Pada DM tipe-1 yang tidak terkontrol akan terjadi gangguan status gizi. Defisiensi insulin pada DM tipe-1 akan mengurangi ambilan glukosa oleh otot, jaringan lunak, jaringan splanikus dan akan terjadi peningkatan glikogenolisis dan glukoneogenesis, berkurangnya ambilan asam amino dan sintesis protein, sehingga pemenuhan nitrogen otot kurang. Katabolisme protein juga meningkat, sehingga secara klinis massa otot di jaringan perifer berkurang mengakibatkan penurunan berat badan (4).

Anak dengan diabetes berisiko mengalami gangguan pertumbuhan akibat proses penyakit atau komplikasinya. Kontrol metabolik yang buruk dapat mengakibatkan gangguan pertumbuhan (berat dan tinggi badan tidak naik secara adekuat) dan perkembangan pubertas yang terlambat (sindrom Mauriac) $(4,13)$. Suatu studi di India menunjukkan anak dengan diabetes tipe 1 usia 4-16 tahun memiliki height velocity lebih rendah dibandingkan anak sehat (14). Pemantauan pertumbuhan perlu dilakukan pada anak dengan diabetes agar dapat dilakukan tatalaksana adekuat, sehingga mereka dapat mencapai tinggi badan akhir optimal sesuai populasi umum (4).

Kontrol glikemik berkaitan dengan komplikasi mikrovaskular dan makrovaskuler. Dengan adanya kontrol glikemik yang baik dapat meningkatkan kualitas hidup pasien DM Tipe 1. Kadar HbA1c yang tinggi menunjukkan buruknya kontrol glikemik. Status vitamin D merupakan salah satu faktor yang dikaitkan dengan kontrol glikemik pada anak dan remaja dengan DM Tipe 1 (15). Kontrol metabolik yang buruk dapat mengakibatkan gangguan status gizi dan pertumbuhan. Vitamin D mempunyai peran penting dalam pertumbuhan tulang. Penelitian ini dilakukan untuk mengetahui hubungan antara status vitamin D (25(OH)D), status kontrol glikemik dan status gizi pada anak dengan DM tipe 1.

\section{METODE}

Penelitian ini adalah penelitian observasional analitik dengan desain cross-sectional yang mengukur kadar vitamin D (25(OH)D, HbA1c dan status gizi (berdasarkan berat badan dan tinggi badan) pada anak DM tipe 1. Populasi penelitian ini adalah pasien anak DM tipe 1 yang menjalani rawat jalan di Klinik Endokrinologi Rumah Sakit Umum dr. Saiful Anwar Malang selama periode Oktober 2017 - Desember 2017 dan rutin mendapatkan terapi insulin dan belum mendapatkan terapi suplementasi vitamin D.

Sesuai dengan perhitungan didapatkan besar sampel minimal adalah 13 sampel (16), pada penelitian ini menggunakan 28 sampel. Kriteria inklusi sampel meliputi: tergolong dalam DM tipe 1, usia antara 2 sampai 18 tahun dan orangtua menyetujui untuk mengikuti penelitian. Pasien anak DM tipe 1 yang menderita penyakit autoimun lain, infeksi berat gangguan hati, gangguan fungsi ginjal, dan anemia tidak disertakan dalam penelitian ini. Pasien DM tipe 1 ditetapkan berdasarkan salah satu dari kriteria berikut: (1) gejala hiperglikemia termasuk poliuria, polidipsia, penurunan berat badan ditambah kadar glukosa plasma darah sewaktu $>200 \mathrm{mg} / \mathrm{dl}(11,1 \mathrm{mmol} / \mathrm{L})$, (2) glukosa darah puasa(>8 jam) $\geq 126 \mathrm{mg} / \mathrm{dl}(\geq 7,0 \mathrm{mmol} / \mathrm{L})$, (3) pada penderita yang asimtomatis ditemukan kadar glukosa darah sewaktu $>200 \mathrm{mg} / \mathrm{dl}$ atau kadar glukosa 
darah puasa lebih tinggi dari normal dengan tes toleransi glukosa yang terganggu pada lebih dari satu kali pemeriksaan. Penelitian ini telah disetujui oleh Komisi Etik rumah sakit Saiful Anwar Malang dengan nomor 4000/01/K.3/302/2018.

Kadar vitamin D adalah kadar $25(\mathrm{OH}) \mathrm{D}$ yang diukur dalam plasma menggunakan metode Enzyme-linked Immuno Assay (ELISA). Kadar 25(OH)D serum diklasfikasikan menjadi: normal $>30 \mathrm{ng} / \mathrm{ml}$, insufisiensi $21-29 \mathrm{ng} / \mathrm{ml}$, dan defisiensi jika $<20 \mathrm{ng} / \mathrm{ml}$. HbA1c adalah glukosa yang terikat pada hemoglobin (glycated haemoglobin) yang berfungsi untuk melihat kadar glukosa darah rata-rata selama periode 3 bulan. Pemeriksaan diukur dengan alat Bio-Rad D-10 ${ }^{\mathrm{TM}}$ di Laboratorium Sentral Patologi Klinik RSSA Malang. Digunakan kriteria berikut untuk pengelompokan kadar HbA1c: $<7,5 \%$ (kontrol metabolik baik), 7,5\%-9\% (kontrol metabolik suboptimal) dan $>9 \%$ (kontrol metabolik buruk).

\section{Pengukuran Berat Badan, Tinggi Badan, dan Status Gizi}

Berat badan anak ditimbang dengan timbangan berdiri. Sebelum penimbangan dilakukan pemeriksaan untuk memastikan alat sudah dalam keadan seimbang (jarum menunjukkan angka 0). Anak ditimbang dalam posisi berdiri tanpa sepatu dengan pakaian minimal. Pengukuran tinggi badan dilakukan dengan posisi anak berdiri tanpa bantuan, tinggi badan diukur dengan stadiometer. Dalam pengukuran tinggi badan, anak diukur tanpa alas kaki atau kaos kaki dan dengan pakaian minimal, saat pengukuran anak harus berdiri tegak, kedua kaki menempel, tumit, bokong dan belakang kepala menyentuh stadiometer dan menatap ke depan pada bidang datar. Berat badan diukur dalam satuan kilogram dan tinggi badan diukur dalam satuan sentimeter kemudian diplotkan pada kurva CDC atau WHO sesuai usia penderita.

Status gizi ditentukan berdasarkan berat badan dan tinggi badan, untuk usia $<5$ tahun menggunakan grafik WHO) dan usia $>5$ tahun menggunakan grafik CDC. Subjek disebut gizi kurang bila BB/TB -3 SD s/d -2 SD menurut WHO atau BB/TB 70-90\% menurut CDC, gizi baik bila $2 S D$ s/d +2 SD menurut WHO atau BB/TB $90-110 \%$ menurut $C D C$, gizi lebih bila $B B / T B+2 S D s / d+3 S D$ atau $\mathrm{BB} / \mathrm{TB}>110-120 \%$ menurut CDC, dan obesitas bila BB/TB +3 SD atau BB/TB $>120 \%$ menurut CDC. Subjek dengan $\mathrm{BB} / \mathrm{TB}>110 \%$, dianalisis lebih lanjut dengan mengukur indeks massa tubuh (IMT) dengan rumus: BB $(\mathrm{kg}) / \mathrm{TB}^{2}$ (meter) dan dilakukan plot ke grafik IMT menurut umur dan jenis kelamin.

\section{Pemeriksaan Kadar HbA1c dan 25(OH)D}

Pemeriksaan kadar HbA1c mengunakan sampel darah utuh (whole blood) diperiksa dengan alat Bio-Rad D-10 ${ }^{\mathrm{TM}}$ dengan metode metode high-performance liquid chromatography (HPLC). Pemeriksaan kadar vitamin D (25(OH)D) menggunakan sampel plasma dengan metode Enzyme-linked Immuno Assay (ELISA), dilakukan di Laboratorium Patologi Klinik RS Saiful Anwar Malang. Kit yang digunakan adalah Alegria Human Vitamin $D$ kit nomor katalog ORG 270 dengan satuan ng/mL.

\section{Analisis Statistik}

Analisis statistik menggunakan SPSS versi 17. Data hasil penelitian disajikan dalam bentuk tabel distribusi frekuensi. Beda rerata kadar vitamin D dan $\mathrm{HbA1C}$ berdasarkan status gizi, dilakukan menggunakan uji Kruskal-Wallis karena data tidak terdistribusi normal.
Untuk uji korelasi antara status gizi dan status vitamin D serta status gizi dengan status kontrol glikemik digunakan analisis korelasi rank Spearman.

\section{HASIL}

Tabel 1 menunjukkan perbandingan rasio jenis kelamin lelaki terhadap perempuan adalah 3:4. Kelompok usia terbanyak (57\%) yaitu $>12-18$ tahun sedangkan kelompok usia 5-12 tahun sebanyak 12 orang, rerata usia 12,64 $\pm 3,19$ tahun dan kurang lebih separo berada pada masa pubertas. Secara klinis subjek sebagian besar mempunyai gizi baik, mengalami insufisiensi dan defisiensi vitamin D, serta kontrol glikemik yang buruk.

Tabel 1. Karakteristik subjek penelitian $(n=28)$

\begin{tabular}{|c|c|}
\hline Karakteristik sampel & $n(\%)$ \\
\hline \multicolumn{2}{|l|}{ Jenis kelamin, $n$} \\
\hline Laki-laki & $12(43)$ \\
\hline Perempuan & $16(57)$ \\
\hline \multicolumn{2}{|l|}{ Usia } \\
\hline $2-<5$ tahun & 0 \\
\hline 5-12 tahun & $12(43)$ \\
\hline$>12-18$ tahun & $16(57)$ \\
\hline Usia, rerata (SD), tahun & $12,6(3,19)$ \\
\hline \multicolumn{2}{|l|}{ Status Gizi, $n$} \\
\hline Gizi baik & $19(68)$ \\
\hline Gizi kurang & $7(25)$ \\
\hline Gizi lebih & $2(7)$ \\
\hline \multicolumn{2}{|l|}{ Status vitamin $\mathrm{D}((25() \mathrm{H}) \mathrm{D}), n$} \\
\hline Defisiensi & $11(39)$ \\
\hline Insufisiensi & $6(21)$ \\
\hline Sufisiensi & $11(39)$ \\
\hline \multicolumn{2}{|l|}{ Status kontrol Glikemik, $n$} \\
\hline Baik & $7(25)$ \\
\hline Suboptimal & $3(11)$ \\
\hline Buruk & $18(64)$ \\
\hline \multicolumn{2}{|l|}{ Frekuensi pemantauan gula darah mandiri, $n$} \\
\hline $1-2 x /$ hari & 28 \\
\hline$>2 x /$ hari & 0 \\
\hline \multicolumn{2}{|l|}{ Status pubertas, $n$} \\
\hline Belum pubertas & $13(46)$ \\
\hline Pubertas & $15(54)$ \\
\hline Dosis insulin/kgBB (IU), rerata $(S D), I U$ & $1,1(0,3)$ \\
\hline Kadar GDP (mg/dL) , rerata $(S D), \mathrm{mg} / \mathrm{dl}$ & $146(76,1)$ \\
\hline Kadar GDS (mg/dL), rerata $(S D), m g / d l$ & $122(52,1)$ \\
\hline
\end{tabular}

Tabel 2 menunjukkan kadar HbA1c yang hampir sama pada status gizi yang berbeda dengan kadar terendah pada status gizi lebih. Kadar vitamin D pada ketiga kelompok status gizi juga hampir sama dengan kadar terendah pada status gizi kurang. Secara statistik juga tidak ditemukan perbedaan kadar HbA1c maupun vitamin D pada subjek pasien DM tipe 1 anak dengan tiga status gizi yang berbeda.

Tabel 2. Perbedaan kadar kadar HbA1c, vitamin D (25(OH)D) pada status gizi

\begin{tabular}{lrrrr}
\hline \multirow{2}{*}{ Variabel } & \multicolumn{3}{c}{ Status Gizi } & \multirow{2}{*}{ p } \\
\cline { 2 - 4 } & \multicolumn{1}{c}{ Baik } & \multicolumn{1}{c}{ Kurang } & \multicolumn{1}{c}{ Lebih } & \\
\hline Vitamin D (25(OH)D) & $24,61 \pm 12,32$ & $23,72 \pm 16,19$ & $24,00 \pm 12,02$ & 0,989 \\
HbA1c & $10,43 \pm 2,92$ & $10,74 \pm 4,18$ & $9,70 \pm 2,26$ & 0,995 \\
\hline
\end{tabular}


Subjek dengan status gizi yang baik ditemukan dengan proporsi yang hampir sama pada ketiga kondisi status vitamin $\mathrm{D}$ (Tabel 3). Mereka yang dinyatakan mempunyai status gizi kurang maupun lebih tidak ada yang mengalami insufisiensi. Hasil uji korelasi rank Spearman memberikan konfirmasi tidak ada hubungan yang signifikan antara status gizi dan status vitamin $D(r=0,079, p=0,689)$.

Tabel 3. Hubungan status gizi dengan status vitamin D

\begin{tabular}{lrrrrrr}
\hline \multirow{2}{*}{ Variabel } & \multicolumn{2}{c}{ Status vitamin D (25(OH)D) } & \multirow{2}{*}{ Total } & R & p-value \\
\cline { 2 - 7 } & defisiensi & Insufisiensi & sufisiensi & & & \\
\hline Status Gizi & 7 & 6 & 6 & 19 & & \\
- baik & 3 & 0 & 4 & 7 & 0,079 & 0,689 \\
- kurang & 1 & 0 & 1 & 2 & & \\
- lebih & 11 & 6 & 11 & 28 & & \\
\hline Total & 1 & & & &
\end{tabular}

Uji korelasi menemukan tidak ada hubungan signifikan antara status gizi dan status vitamin D dengan status kontrol glikemik (Tabel 4). Sebagian besar subjek menunjukkan kontrol glikemik yang buruk meskipun dengan status gizi baik. Proporsi subjek dengan defisiensi maupun sufisiensi vitamin $\mathrm{D}$ berimbang.

Tabel 4. Hubungan status gizi dan vitamin D dengan status kontrol glikemik

\begin{tabular}{|c|c|c|c|c|c|c|}
\hline \multirow{2}{*}{ Variabel } & \multicolumn{3}{|c|}{ Status kontrol glikemik } & \multirow{2}{*}{ Total } & \multirow{2}{*}{$r$} & \multirow{2}{*}{$\begin{array}{c}p- \\
\text { value }\end{array}$} \\
\hline & baik & suboptimal & buruk & & & \\
\hline \multicolumn{7}{|l|}{ Status Gizi } \\
\hline - baik & 5 & 1 & 13 & 19 & & \\
\hline - kurang & 2 & 1 & 4 & 7 & $-0,062$ & 0,752 \\
\hline - lebih & 0 & 1 & 1 & 2 & & \\
\hline \multicolumn{7}{|l|}{ Status Vitamin D } \\
\hline - defisiensi & 3 & 2 & 6 & 11 & & \\
\hline - insufiensi & 1 & 0 & 5 & 6 & 0,062 & 0,755 \\
\hline - sufiensi & 3 & 1 & 7 & 11 & & \\
\hline Total & $7(25 \%)$ & $3(11 \%)$ & $18(64 \%)$ & 28 & & \\
\hline
\end{tabular}

\section{DISKUSI}

Penelitian ini mengidenitifikasi 28 subjek anak dengan DM tipe 1 yang sebagian besar perempuan dengan rentang usia terbanyak 13-18 tahun. Pada penelitian ini didapatkan 28 anak dengan diabetes melitus tipe I sebagai subjek penelitian. Karakteristik usia subjek berada pada rentang usia 7-17 tahun dengan rata-rata usia 12 tahun. $\mathrm{Hal}$ ini sesuai dengan epidemiologi sebelumnya bahwa puncak kejadian DM tipe 1 adalah usia 5-7 tahun dan saat usia 10-14 tahun atau pubertas (2,8). Berdasarkan distribusi jenis kelamin didapatkan distribusi anak perempuan lebih banyak dibandingkan anak laki-laki (4:3). Hal ini sesuai dengan data penelitian di Amerika serikat angka kejadian terbanyak pada rentang usia 9-12 tahun dan anak perempuan dua kali lebih banyak daripada anak laki-laki (17). Sebaliknya data dari IDF pada tahun 2011 menyebutkan bahwa laki-laki lebih banyak dibandingkan perempuan sebanyak 1,5 kali lipat. Data ISPAD pada tahun yang sama menyebutkan bahwa perbedaan jenis kelamin terhadap insiden DM tipe 1 di sebagian negara tidak berbeda (3). Adanya perbedaan ini disebabkan oleh perbedaan populasi, ras serta jumlah subjek penelitian (18).

\section{Status Gizi dan Kontrol Glikemik}

Pada penelitian ini didapatkan sebagian besar subjek mempunyai status gizi baik (68\%) dan tidak ada hubungan antara status gizi dengan status kontrol glikemik dan status vitamin D. Penelitian di Brasil juga menunjukkan 59\% penderita DM tipe 1 dengan gizi baik, 1\% dengan gizi kurang, dan 40\% dengan gizi lebih (19). Sementara penelitian di RSSA Malang periode 2005-2009 menemukan 27 anak DM tipe 1 yang sebagian besar mengalami malnutrisi sedang (20). Pada DM tipe 1 penurunan sekresi insulin yang terjadi adalah akibat autoimun bukan disebabkan oleh penurunan sensitivitas insulin seperti pada DM tipe lainnya, sehingga status gizi tidak berpengaruh langsung (21). Anak diabetes dengan terapi insulin yang adekuat serta perbaikan kontrol metabolik, akan mengalami penambahan berat badan. Penambahan berat badan yang terlalu banyak menunjukkan kelebihan diet di atas kebutuhannya serta kemungkinan dosis insulin yang berlebih (22).

Pada penelitian ini didapatkan 54\% dari 28 subjek telah mengalami pubertas, rata-rata dosis insulin yang digunakan pada penelitian ini adalah $1,14 \pm 0,26$ $\mathrm{IU} / \mathrm{kg} /$ hari. Didapatkan 2 anak dengan status gizi lebih dengan rentang dosis insulin 0,5-1 IU/ kg/hari. Status gizi lebih pada penelitian ini dapat disebabkan kelebihan diet di atas kebutuhan anak, tetapi jumlah diet yang bisa berpengaruh pada status gizi anak tidak diteliti dalam penelitian ini. Awitan, puncak kerja, dan lama kerja insulin merupakan faktor yang menentukan dalam pengelolaan penderita DM. Penyesuaian dosis insulin bertujuan untuk mencapai kontrol metabolik yang optimal, tanpa meningkatkan risiko terjadinya hipoglikemia dan tanpa mengabaikan kualitas hidup penderita baik jangka pendek maupun jangka panjang. Selama periode "honeymoon" total dosis insulin harian $<0,5 \mathrm{lU} / \mathrm{kgBB} /$ hari, anak sebelum pubertas (diluar periode"honeymoon") dalam kisaran dosis 0,7-1 IU/kgBB/hari. Selama pubertas kebutuhan insulin meningkat diatas 1 IU sampai dengan 2 $\mathrm{IU} / \mathrm{kgBB} /$ hari. Pada masa remaja, kebutuhan insulin meningkat karena kerja hormon steroid seks, meningkatnya amplitudo dan frekuensi sekresi growth hormone, kesemuanya merupakan hormon anti insulin (4). Anak dengan diabetes tipe 1 memiliki height velocity lebih rendah dibandingkan anak sehat, salah satu faktor risiko terjadinya gagal tumbuh adalah semakin muda usia saat terdiagnosis (Parthasaray). Lamanya menderita penyakit dan kadar HbA1C mempengaruhi height velocity (14).

\section{Status Vitamin D}

Status vitamin D pada sampel penelitian didominasi dengan kadar 25(OH)D yang tidak normal, baik defisiensi sebanyak 39\% maupun insufisiensi sebanyak 21\% dari 28 subjek. Tidak ada perbedaan bermakna kadar 25(OH)D pada kelompok status gizi. Studi oleh Hasan juga mengidentifikasi defisiensi vitamin $D$ pada anak dengan DM tipe 1 sebanyak 91.67\%, serta tidak didapatkan hubungan signifikan antar serum vitamin D, serum kalsium, fosfor, status antropometri, lama sakit diabetes, rerata $\mathrm{HbA1C}$, dosis insulin dan paparan sinar matahari (23). Studi cross sectional di Belanda menunjukkan 60-84\% pasien DM tipe 1 terjadi defisiensi vitamin D (10). Demikian studi di Amerika, dari 128 pasien DM tipe 1 didapatkan $15 \%$ pasien dengan defisiensi $25(\mathrm{OH}) \mathrm{D}, 61 \%$ 
dengan kadar $25(\mathrm{OH}) \mathrm{D}$ yang insufisien, dan $24 \%$ sufisien (15). Studi lain di Arab Saudi, India Utara dan Australia mendapatkan bahwa anak dengan DM tipe 1 mempunyai kadar $25(\mathrm{OH}) \mathrm{D}_{3}$ yang rendah dibandingkan populasi normal $(11,24)$. Penelitian yang dilakukan di Indonesia juga mendapatkan hasil yang serupa yaitu pada penderita DM tipe 1 banyak yang mengalami defisiensi maupun insufisiensi vitamin D. Salah satu penelitian yang dilakukan di RSSA Malang didapatkan $90 \%$ anak dengan DM tipe 1 memiliki kadar $25(\mathrm{OH}) \mathrm{D}_{3}$ yang rendah (25). Berdasarkan status gizinya, terdapat 2 pasien dengan gizi lebih $(\mathrm{BBI}>110)$ dengan $\mathrm{BMI}>25$. Pada pasien ini kadar vitamin $D$ berada dalam status defisiensi dan satu insufisiensi. Pada pasien yang gemuk terjadi penurunan dari bioavailabilitas vitamin dikarenakan adanya sequestrasi vitamin D dalam jaringan lemak (26).

Defisiensi vitamin D dipengaruhi oleh faktor genetik dan faktor lingkungan. Indonesia sebagai negara tropis yang terletak di katulistiwa dengan paparan sinar matahari yang didapatkan sepanjang tahun, menjadikan Indonesia cukup untuk sintesis vitamin D (27). Penurunan sintesis vitamin D disebabkan oleh penggunaan tabir surya, pigmen kulit yang gelap, usia, musim, letak lintang yang menjauhi equator, jumlah waktu paparan sinar matahari, cara berpakaian yang tertutup dan adanya lesi pada kulit. Penurunan bioavailabilitas vitamin D dapat disebabkan oleh adanya malabsorbsi dan obesitas. Peningkatan katabolisme vitamin D dapat disebabkan oleh penggunaan obat-obatan seperti antikonvulsan dan glukokortikoid. Penurunan sintesis vitamin $\mathrm{D}$ dapat disebabkan karena gangguan liver. Hilangnya vitamin D lewat urin dapat terjadi pada sindroma nefrotik. Adanya penyakit ginjal kronis dapat mengurangi sintesis dari vitamin D. Pada anak, penyebab tersering defisiensi vitamin $D$ adalah pemberian ASI tanpa suplementasi vitamin D, kurangnya paparan sinar matahari dan diet kurang vitamin $D(26,28)$.

Pada penelitian ini didapatkan kadar vitamin D yang rendah hal ini bisa disebabkan kurangnya paparan sinar matahari dan diet kurang vitamin D. Pada penelitian ini memang tidak meneliti seberapa lama (jumlah paparan sinar matahari) dan tidak mengukur jenis diet yang mengandung vitamin $D$ pada subjek penelitian. Kontribusi genetik terbanyak dari locus DM tipe 1 adalah gen HLA kelas II yang terletak di kromosom 6p21.3. Locus HLA-DR dan HLA-DQ di regio kelas II mempunyai risiko yang sangat kuat terhadap terjadinya DM tipe 1 (29). Adanya polimorfisme pada VDR (Vitamin D receptor) berhubungan dengan banyak penyakit, yang salah satunya adalah diabetes (30). Adanya polimorfisme VDR menyebabkan vitamin D tidak dapat ditangkap oleh reseptor walaupun kadarnya normal. Selain itu, pengaruh genetik tertentu dan pengaruh lingkungan yang berbeda pada tiap pasien juga dapat mempengaruhi kadar vitamin $\mathrm{D}$ pada pasien.

Individu yang mengalami defisiensi vitamin $D$ berisiko lebih tinggi mengalami gangguan autoimun (31). Supresi pada bone turnover merupakan karakteristik utama dari gangguan tulang terkait DM tipe 1 dan defisiensi vitamin D. Keadaan hiperglikemia, hipoinsulinemia, inflamasi autoimun, kadar insulin-like growth factor-1 dan vitamin D yang rendah diperkirakan berhubungan dengan suppresi bone turnover. Faktor risiko terjadinya penurunan mineralisasi tulang pada DM tipe 1 antara lain: Usia semakin muda saat awal terdiagnosis, kontrol glikemik yang buruk, adanya komplikasi diabetes, fungsi ginjal yang menurun dan BMI yang rendah, serta dosis insulin (32).

\section{Kadar $\mathrm{HbA1C}$}

Penelitian ini menunjukkan tidak ada perbedaan bermakna kadar HbA1C antar kelompok status gizi. Pada penelitian ini, dari 28 subjek penelitian, hanya 7 anak dengan kontrol metabolik baik dan 18 anak dengan kontrol metabolik yang buruk (HbA1c $>9 \%$ ). Pemeriksaan $\mathrm{HbA1c}$ dipergunakan untuk menggambarkan kontrol glukosa jangka panjang, menggambarkan kondisi 8-12 minggu sebelumnya, karena paruh waktu eritrosit 120 hari (33).

Kemungkinan yang bisa menyebabkan kadar HbA1c yang tinggi adalah hubungan antara terbatasnya ketersediaan insulin dan kurangnya pemantauan gula darah mandiri. Penyimpanan insulin mungkin mempengaruhi efek dari insulin, seperti menyimpan insulin dalam freezer, atau paparan insulin dengan sinar matahari langsung (34). Dari beberapa penelitian telah dibuktikan hubungan yang bermakna antara pemantauan mandiri dan kontrol glikemik. Pengukuran kadar glukosa darah harus dilakukan beberapa kali per hari untuk menghindari terjadinya hipoglikemia dan hiperglikemia, serta penyesuaian dosis insulin. Kadar glukosa darah preprandial, post prandial, dan tengah malam sangat diperlukan untuk penyesuaian dosis insulin (4). Pada penelitian ini frekuensi pemantauan glukosa darah sebanyak $1-2 x$ /hari pada seluruh sampel penelitian, hal ini menunjukkan masih kurangnya pemantauan.

Penelitian retrospektif tentang pengaruh DM tipe 1 terhadap pertumbuhan oleh Korcan et al., menunjukkan hubungan negatif $\mathrm{HbA} 1 \mathrm{C}$ dengan tinggi badan pada 3 tahun setelah terdagnosis (35). Studi di Iran menunjukkan pada onset awal penyakit DM tipe 1 didapatkan 44,6\% mengalami KAD, rerata $\mathrm{HbA} 1 \mathrm{C} 8,89 \%$. Perbedaan signifikan berat badan SDS hanya terlihat pada pasien dengan kontrol metabolik baik dan yang buruk. Kontrol metabolik yang buruk dapat menurunkan pertumbuhan tinggi badan dan sedikit mempengaruhi berat badan (36). Studi kohort di Meksiko 2016 mendapatkan 50\% mengalami gagal tumbuh. Hasil analisis multivariat faktor yang berhubungan dengan gagal tumbuh adalah kadar $\mathrm{HbA1c}$ pada tahun pertama terdiagnosis (37).

Pada penelitian ini tidak didapatkan hubungan yang signifikan antara status vitamin $\mathrm{D}(25(\mathrm{OH}) \mathrm{D})$ dan status HbA1c. Penelitian Branco et al., juga membuktikan bahwa tidak terdapat hubungan antara kadar $\mathrm{HbA1c}$ dan $25(\mathrm{OH}) \mathrm{D}$ namun status vitamin $D$ berbeda bermakna antar jenis kelamin (38). Penelitian sebelumnya justru menunjukkan memiliki korelasi negatif artinya semakin tinggi kadar 25(OH)D maka semakin rendah kadar HbA1c. Penelitian ini dilakukan selama 3 bulan tanpa tindakan intervensi pemberian vitamin $\mathrm{D}$ (39).

Pada DM tipe 1 terjadi ketidakseimbangan antara sitokin pro inflamasi dan sitokin anti inflamasi. Pada tingkat APC, vitamin D menghambat ekspresi permukaan kompleks MHC kelas II dan molekul ko-stimulator, dan juga produksi dari IL-12, yang mengarahkan polarisasi sel T dari fenotif Th1 ke arah Th2. Lebih lanjut, vitamin D memiliki efek immunomodulator secara tidak langsung pada tingkat sel T, melalui penghambatan sitokin inflamasi Th1 yaitu IL-2 dan IFN- $y$ dan menstimulasi produksi sitokin Th2 yaitu IL4,IL5 dan IL 10. Secara bersamaan, efek immunomodulasi dari vitamin $\mathrm{D}$ ini mengarah pada perlindungan jaringan target seperti sel beta (40). Pada penelitian ini tidak diperiksa sitokin inflamasi atau antiinflamasi untuk 
mengetahui pengaruh terhadap vitamin $D((25(\mathrm{OH}) \mathrm{D})$ dan kontrol glikemik (HbA1c).

Keterbatasan pada penelitian ini adalah meneliti kadar HbA1c dan vitamin D dan status gizi dalam satu kali pengukuran, diperlukan pengukuran serial agar dapat mengetahui lebih jauh hubungan antar variabel penelitian. Penelitian ini dilakukan hanya pada populasi anak DM tipe 1 dan tidak ada kontrol anak sehat. Kadar $\mathrm{HbA1c}$ banyak dipengaruhi oleh beberapa faktor antara lain kadar besi, vitamin B12 dan asam folat yang tidak diperiksa dalam penelitian ini. Faktor-faktor penyulit yang mungkin timbul pada penelitian ini juga belum dapat dikendalikan seideal mungkin, seperti misalnya, faktor diet rendah vitamin $\mathrm{D}$, paparan terhadap sinar matahari, etnis/ras, luas permukaan tubuh, dan obat-obatan yang dapat mempengaruhi status vitamin D pada subjek

\section{DAFTAR PUSTAKA}

1. Zóka A, Mǔzes G, Somogyi A, et al. Altered Immune Regulation in Type 1 Diabetes. Clinical and Developmental Immunology. 2013; 10(7): 1-17.

2. Sperling Mark A. Pediatric Endocrinology. 4th edition. New York: Elsevier; pp.141-144.

3. Craig ME, Jefferies C, Dabelea D, Balde N, Seth A, and Donaghue KC. Definition, Epidemiology, and Classification of Diabetes in Children and Adolescents. Pediatric Diabetes. 2014; 15(20): 4-17.

4. Tridjaja B, Niken PY, M. Faizi, et al. Konsensus Nasional Pengelolaan Diabetes Melitus Tipe 1. Jakarta: Badan Penerbit Ikatan Dokter Anak Indonesia; 2015; hal.1-10.

5. Laboratorium Rekam Medik. Data Jumlah Pasien Diabetes Melitus di Rumah Sakit Saiful Anwar Malang Periode 2011-2016. Bagian Rekam Medik RSSA. Malang; Rumah Sakit Umum dr. Saiful Anwar; 2016.

6. Mathieu C. Vitamin D and the Immune System: Getting It Right. International Bone \& Mineral Society BoneKEy. 2011; 8(4): 178-186.

7. Baeke F, Takiishi T, Korf H, Gysemans C, and Mathieu C. Vitamin D: Modulator of the Immune System. Current Opinion in Pharmacology. 2010; 10(4): 482496.

8. Takiishi T, Gysemans C, Bouillon R, and Mathieu C. Vitamin $D$ and Diabetes. Endocrinology and Metabolism Clinics of North America. 2010; 39(2): 419-446.

9. Mitri J and Pittas AG. Vitamin D and Diabetes. Endocrinology and Metabolism Clinics of North America. 2014; 43(1): 205-232.

10. Janner M, Ballinari $P$, Mullis $P E$, and Flück CE. High Prevalence of Vitamin D Deficiency in Children and Adolescent with Type 1 Diabetes. Swiss Medical Weekly. 2010; 140: 1-6.

11. Greer S, Portelli L, Hung BS, et al. Serum Vitamin D Levels Are Lower in Australian Children and Adolescents with Type 1 Diabetes Than in Children without Diabetes. Pediatric Diabetes. 2012; 14(1): 31-41. penelitian yang mungkin berperan terhadap terjadinya defisiensi vitamin $D$ yang tidak diperiksa dalam penelitian ini. Perlu pengukuran kadar IGF-1 untuk mengetahui hubungan dengan pertumbuhan tulang yang mempengaruhi tinggi badan anak.

Hasil penelitian menggambarkan bahwa pada anak dengan DM tipe didapatkan jumlah defisiensi yang cukup banyak serta didominasi kontrol glikemik yang buruk walaupun mempunyai status gizi yang baik.

Tidak terdapat perbedaan bermakna kadar $\mathrm{HbA1c}$ dan vitamin D berdasarkan status gizi pada anak DM tipe 1 . Tidak ada hubungan antara status vitamin $D$ dengan status gizi kontrol glikemik dengan status vitamin D pada anak DM tipe 1. Studi lanjut perlu dilakukan dengan menggunakan kelompok kontrol sehat, pemantauan berkala serta mempertimbangkan pengaruh faktor lingkungan.

12. Ginanjar E, Sumariyono, Setiati S, and Setiyohadi B. Vitamin D and Autoimmune Disease. Acta Medica Indonesiana. 2007; 39(3): 133-41.

13. Virmani A. Growth Disorders in Type 1 Diabetes: An Indian Experience. Indian Journal of Endocrinology and Metabolism. 2015; 19(1): S64-S67.

14. Parthasarathy L, Khadilkar V, Chiplonkar S, and Khadilkar V. Longitudinal Growth in Children and Adolescents with Type 1 Diabetes. Indian Pediatrics. 2016; 53(11): 990-992.

15. Svoren BM, Volkening LK, Wood JR, and Laffel LM. Significant Vitamin D Deficiency in Youth with Type 1 Diabetes Mellitus. The Journal of Pediatrics. 2009; 154(1): 132-134.

16. Sastroasmoro S. Pemilihan Subjek Penelitian. Di dalam: Sastroasmoro S dan S Ismal (Eds). Dasardasar Metodologi Penelitian Klinis Edisi 4. Jakarta: Sagung Seto; 2011: hal. 359.

17. Kalyva E, Malakonaki E, Eiser C, and Mamoulakis D. Health-Related Quality of Life (HRQoL) of Children with Type 1 Diabetes Mellitus (T1DM): Self and Parental Perceptions. Pediatric Diabetes. 2011; 12(1): 34-40.

18. Pereira DA, Costa NMSC, Sousa ALL, Jardim PCBV, and Zanini CRO. The Effect of Educational Intervention on the Disease Knowledge of Diabetes Mellitus Patients. The Revista Latino-Americana de Enfermagem. 2012; 20(3): 478-485.

19. da Costa VM, Padilha PC, Lima GCF, et al. Overweight among Children and Adolescent with Type I Diabetes Mellitus: Prevalence and Associated Factors. Diabetology \& Metabolic Syndrome. 2016; 8(39): 118.

20. Cahyono HA. Gambaran Klinis dan Laboratoris Diabetes Melitus Tipe-1 pada Anak. Jurnal Kedokteran Brawijaya. 2013; 26(4): 195-198.

21. Hassanein MA and Sultan I. Evaluation of Nutrition and Health Status among Children with Diabetes. Life Science Journal. 2014; 11(2): 327-334.

22. Batubara J, Susanto R, dan Cahyono HA. Pertumbuhan dan Gangguan Pertumbuhan. Di dalam: Batubara JRL, Tridjaja $B$, dan Pulungan $A B$ (Eds). Buku Ajar Endokrinologi Anak Edisi 1. Jakarta: 
Badan Penerbit Ikatan Dokter Anak Indonesia; 2010; hal. 19-42.

23. Hassan MM, Alashmawy AA, Sharaf FA, et al. Vitamin $D$ Status in Egyptian Children and Adolescents with Type 1 Diabetes Mellitus. Journal of Diabetes \& Metabolism. 2016; 7(1): 1-4.

24. Borkar VV, Devidayal, Verma S, and Bhalla, K. Low Levels of Vitamin $D$ in North Indian Children with Newly Diagnosed Type 1 Diabetes. Pediatric Diabetes. 2010; 11(5): 345-350.

25. Wulandari D, Cahyono HA, Widjajanto $E$, and Puryatni A. Low Levels of Vitamin D correlate with Hemoglobin A1C and Interleukin-10 Levels in Pediatric Type 1 Diabetes Mellitus Patients. The Journal of Tropical Life Science. 2014; 4(3): 182-186.

26. Holick MF. Diabetes and the Vitamin D Connection. Current Diabetes Reports. 2008; 8(5): 393-398.

27. Handono K, Puspitasari L, Rudijanto A, Wahono S, and Kalim H. Vitamin D Serum Level and Disease Activity in Patients with Systemic Lupus Erythematosus. International Journal of Pharmaceutical Science Invention. 2013; 2(2): 3540.

28. Al-Agha $\mathrm{AE}$ and Ahmad IA. Association among Vitamin D Deficiency, Type 1 Diabetes Mellitus and Glycemic Control. Journal of Diabetes Metabolism. 2015; 6(9): 1-5.

29. Rajashree R, Ravishankar MV, Kholkute SD, and Goudar SS. Type 1 Diabetes Mellitus: An Update. International Journal of Diabetes \& Metabolism. 2012; 20(3): 37-42.

30. Balasubramanian S, Dhanalakshmi K, and Amperayani S. Vitamin D Deficiency in Childhood a Review of Current Guidelines on Diagnosis and Management. Endocrine Pediatric Journal. 2013; 50(7): 669-674.

31. Dong JY, Zhang WG, Chen JJ, Zhang ZL, Han SF, and Qin LQ. Vitamin D Intake and Risk of Type 1 Diabetes:
A Meta-Analysis of Observational Studies. Nutrients. 2013; 5(9): 3551-3562.

32. Zhukouskaya VV, Eller Vainicher C, Shepelkevich AP, Dydyshko Y, Cairoli E, and Chiodini I. Bone Health in Type 1 Diabetes: Focus on Evaluation and Treatment in Clinical Practice. Journal of Endocrinological Investigation. 2015; 38(9): 941-950.

33. Sherwani SI, Khan HA, Ekhzaimy A, Masood A, and Sakharkar MK. Significance of HbA1c Test in Diagnosis and Prognosis of Diabetic Patients. Biomarker Insight. 2016; 11: 95-104.

34. International Society for Pediatrics and Adolescent Diabetes. Diabetes in Childhood and Adolescence. ISPAD Clinical Practice Consensus Guidelines. (Online) 2011. https://www.ispad.org/page/ IDFISPAD2011?

35. Demir K, Altıncık A, Abacı A, Büyükgebiz A, and Böber E. Growth of Children with Type 1 Diabetes Mellitus. Journal of Clinical Research Pediatric Endocrinology. 2010; 2(2): 72-77.

36. Assar S, Riahi A, Bashirnezhad S, Yazdanpanah L, and Latifi SM. The Relationship between Metabolic Control and Growth in Children with Type I Diabetes Mellitus in Southwest of Iran. Scientifica. 2015; 2015: 1-5.

37. Cruz JN Z, Martínez GED, Keever MÁV, et al. Pediatric Patients with Type 1-Diabetes: Growth and Growth Failure Associated Factor. Boletin Medico del Hospital Infantil de Mexico. 2016; 73(3): 174-180.

38. Branco S, Rego C, Costa C, et al. Vitamin D Deficiency in Children and Adolescents with Type 1 Diabetes. Pediatric Diabetes. 2012; 13: 91-92.

39. Magee L, Mughal Z, Ehtisham $\mathrm{S}$, et al. The Relationship between Vitamin D and HbA1C in A Type 1 Diabetic Paediatric Population. Endocrine Abstracts. 2012; 28(1): P38.

40. Sesadri KG, Tamilselvan B, and Rajendran A. Role of Vitamin $D$ in Diabetes. Journal of Endocrinology an Metabolism. 2011; 1(2): 47-56. 